九州大学学術情報リポジトリ

Kyushu University Institutional Repository

\title{
Population Densities of Pest Aphids and their Associated Natural Enemies on Faba Bean in Kafr EL-Sheikh, Egypt
}

KHODEIR, A. Ibrahim

Economic Entomology Department, Faculty of Agriculture, Kafrelsheikh University

KHATTAB, A. Mohamed

Plant Protection Research Institute

RAKHA, M. Osama

Economic Entomology Department, Faculty of Agriculture, Kafrelsheikh University

SHARABASH, S. Amina

Plant Protection Research Institute

他

https://doi.org/10.5109/2558900

出版情報: 九州大学大学院農学研究院紀要. 65 (1)，pp.97-102，2020-02. Faculty of Agriculture， Kyushu University

バージョン :

権利関係 : 


\title{
Population Densities of Pest Aphids and their Associated Natural Enemies on Faba Bean in Kafr EL-Sheikh, Egypt
}

\author{
Ibrahim A. KHODEIR ${ }^{1}$, Mohamed A. KHATTAB ${ }^{2}$, Osama M. RAKHA ${ }^{1}$, \\ Amina S. SHARABASH ${ }^{2}$, Takatoshi UENO ${ }^{3 *}$ and Kareem M. MOUSA ${ }^{1,3}$
}

\author{
Laboratory of Insect Natural Enemies, Division of Biological Control, Department of Applied Genetics and Pest Management, \\ Faculty of Agriculture, Kyushu University, Fukuoka 819-0395, Japan \\ (Received October 31, 2019 and accepted November 14, 2019)
}

\begin{abstract}
Population dynamics of insect pests are complex and are dependent on various biotic and abiotic factors. Understanding pest population dynamics and factors affecting them is important for predicting pest outbreaks and constructing the management strategy. Aphids are among the major pest groups in bean crops and aphid outbreaks can frequently occur when the management is inappropriate. In the present study, we examined the population fluctuation and abundance of aphid species and their associated predators and parasitoids in faba bean fields during 2016/17 and 2017/18 seasons in Kafr EL-Shiekh, Egypt. Among four pest aphids detected, Aphis craccivora was the most dominant, followed by Acyrthosiphon pisum while Aphis gossypii and Myzus persicae were found in low densities throughout the season. Although A. craccivora was detected throughout the growing season, the density is notably high in the early growth stage of faba bean. Among the predators, Chrysoperla carnea and true spiders (Singa sp. and Dictyna sp. were most abundant, followed by Coccinella undecimpunctata. The other common predators were Scymnus spp., Paederous alfierii, and Orius sp. A. craccivora was found to be parasitized by the parasitoid Aphidius spp., and the percentages of parasitism were high in the beginning of growth season then declined to zero before the middle of the season. The importance of pest aphids and their natural enemies in faba bean fields was discussed.
\end{abstract}

Key words: Pest management, Vicia faba, seasonal abundance, natural enemies, parasitism rate

\section{INTRODUCTION}

Faba bean (broad bean) Vicia faba L. is the third most important legume in the world. For its nutritive and growth characteristics, faba bean is a main cool season legume. The legume grains contain a great proportion of protein (28\%) and carbohydrates (58\%), as well as vitamins (Gupta, 1982). Also, faba bean plants have ancillary benefits of nitrogen fixation in the soil and thus require a low fertility requirement. Because of these, faba bean is one of the most important crops in Egypt and other part of the world.

Significant yield losses of faba bean occur due to attack by multiple insect pests either in the open field or during the storage process. Aphids are among the most serious and widespread insect pests attacking faba bean in many geographical regions (Radcliffe et al., 1993), and, in Egypt, they infest faba bean plants all over the country causing considerable yield losses due to direct feeding by sucking plant sap or to indirect transmission of virus diseases (Hull, 1964; Hannou, 1995; El-Defrawi and Mokhtar, 2007; Khattab et al., 2014). Black bean aphid Aphis fabae Scopoli, cowpea aphid Aphis craccivora Koch and pea aphid Acrythosiphon pisum Harris are the most important widespread species infest-

Economic Entomology Department, Faculty of Agriculture, Kafrelsheikh University, Kafr El-Sheikh 33-516, Egypt

Plant Protection Research Institute, ARC, Giza, Egypt

Institute of Biological Control, Faculty of Agriculture, Kyushu University, Fukuoka 819-0395, Japan

* Corresponding author (E-mail: ueno@grt.kyushu-u.ac.jp) ing faba bean in Egypt, and are the major targets of pest management programs in legume crops (Hossni, 2004; Mousa et al., 2019)

In commercial plantings, farmers often use aphidicides in the form of foliar sprays to control pest aphids. This practice can often lead to unwelcome consequences such as undesirable deleterious impacts on natural enemies, development of insecticide resistance, etc., and, hence, chemical control of aphids may turn into an ineffective method (Denholm and Rowland, 1992; Radcliffe et al., 1993; Ueno, 2006). Therefore, incorporation of other practices such as use of plant extracts, natural substances, intercropping and resistant varieties is on demand to reduce aphid pest incursions (Dent, 2000; Mousa et al., 2013; Elsharkawy and Mousa, 2015; Tran et al., 2016; 2017; Sun et al., 2018; Mousa and Ueno, 2019).

Keeping pest infestation below an economically injury level is the fundamental process as preventative measures in long-term integrated pest management programs (Dent, 2000). Also, the timing of insecticide applications is based on the economic threshold level in order to maximize the efficiency of controlling methods and to preserve insect natural enemies. These practices would save the amounts of insecticides, labor, fuel and other materials. However, to do such practices, we need the fundamental knowledge of population dynamics of target pests and their natural enemies, as well as the species compositions of both pests and natural enemies.

In the present study, we focus on pest aphids in faba bean fields of Kafr El-Sheikh areas in Egypt where aphid control is crucial to stable production of faba bean. Our current knowledge and understanding of population 
dynamics of aphids and their natural enemies have been limited. Thus, the aim of the present study is to examine the population trends, species composition and the seasonal abundance of most dominant aphid species and their associated natural enemies. For these purposes, we made a series of field studies for two years faba bean open fields in Kafr EL-Sheikh. Based on the results, we discuss on the importance of pest aphids and their natural enemies in faba bean fields.

\section{MATERIALS AND METHODS}

\section{Study fields}

The present study was carried out in the Experimental Farm of Sakha Agricultural Research Station, Kafr El-Sheikh Governorate during faba bean planting seasons in two successive years 2016/2017 and 2017/2018. A field of one feddan (equal to $4200.8 \mathrm{~m}^{2}$ ) was divided into four parts of the same size and cultivated with an early mature variety of faba bean, Sakha 4 , from the third week of November during the two study seasons. The variety Sakha 4 was obtained from Legumes Research Department, Sakha Agricultural Research Station. Regular conventional practices were performed and no insecticides were applied during the study period.

\section{Survey of aphid species and associated predators}

Populations of aphids and associated predators were monitored weekly from Dec. $20^{\text {th }} 2016$ till Apr. $4^{\text {th }} 2017$ in the first study season and from Dec. $16^{\text {th }} 2017$ till Mar. $31^{\text {st }} 2018$ in the second season. Field surveys were carried out in the morning time. 15 faba bean plants were randomly selected form each part using a cross diameter method and the whole plant was inspected in the field. Aphids and the associated predators that were detected were identified and counted with the aid of $8 x$ lens.

\section{Parasitism rate}

The importance of aphid parasitoids was assessed by investigating the percentages of parasitism of the most dominant aphid, Aphis craccivora. Every week, bean plants infested with aphids were chosen and transferred to the laboratory. Then, 50 aphid individuals were randomly collected from the plants and were divided into five groups in petri dishes (10 insects/petri dish). The aphids in petri dishes were supplied with fresh faba bean leaves. They were daily observed for the formation of mummies. Rate of parasitism was estimated according to Farrell and Stufkens (1990) as percentage of parasitism $=$ the number of mummified aphids/total number of aphids $\times 100$. Mummies were reared until parasitoid emergence. The percentage of parasitoids that had successfully emerged from mummified aphids was then calculated.

\section{Dominance percentages}

Using the above mentioned data set, dominance percentages of aphid species and natural enemies were determined by the formula of Fasulati (1971); domi- nance percentage $=(\mathrm{t} / \mathrm{T}) \times 100$, where $\mathrm{t}$ is the total number of each species, and $\mathrm{T}$ is the total number of all species counted.

\section{Data analyses}

The data were analyzed using COSTAT software.

\section{RESULTS AND DISCUSSION}

\section{Pest aphids}

Field surveys for two successive seasons in 2016/2017 and 2017/2018 revealed population dynamics of pest aphids in faba bean fields. We showed in Fig. 1 the seasonal prevalence of four aphid species detected, i.e., cowpea aphid Aphis craccivora Koch., cotton aphid Aphis gossypii (Glov.), green peach aphid Myzus persicae (Sulzer) and pea aphid Acyrthosiphon pisum (Harris), which belong to the family Aphididae in Homoptera.

Cowpea aphid A. craccivora appeared from the beginning of planting season (Dec. $20^{\text {th }}$ and Dec. $16^{\text {th }}$ in the 2016/2017 and 2017/2018 surveys, respectively) when the densities were not high. However, the populations of $A$. craccivora increased rapidly, forming one peak on Jan. $3^{\text {rd }}$ with $307.0 \pm 222.5$ individuals recorded (mean \pm SD) in 2016/2017; in 2017/2018, there was also one distinct peak, which appeared on Dec. $30^{\text {th }}$ with $176.0 \pm 154.0$ individuals (Fig. 1). The other three species of pest aphids, i.e., A. gossypii, M. persicae and A. pisum, appeared one week later than $A$. craccivora, and their densities mostly remained very low until harvest (Fig. 1). Pea aphid A. pisum was rather rare until
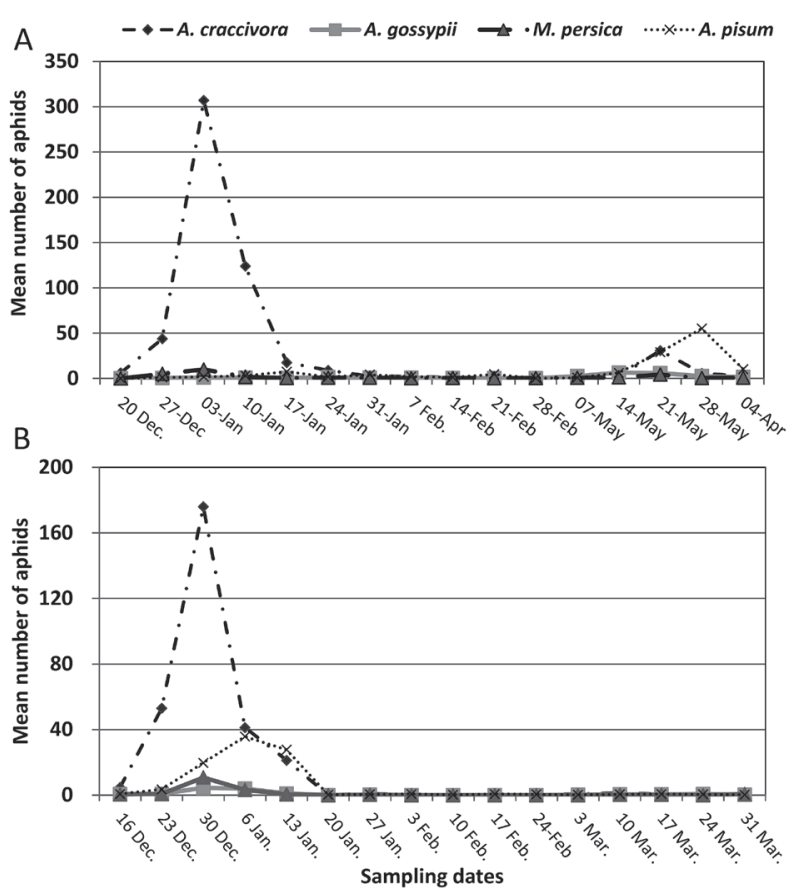

Fig. 1. Mean weekly abundance of four aphid species occurred in faba bean fields during 2016/2017 (A) and 2017/2018 (B) seasons. 


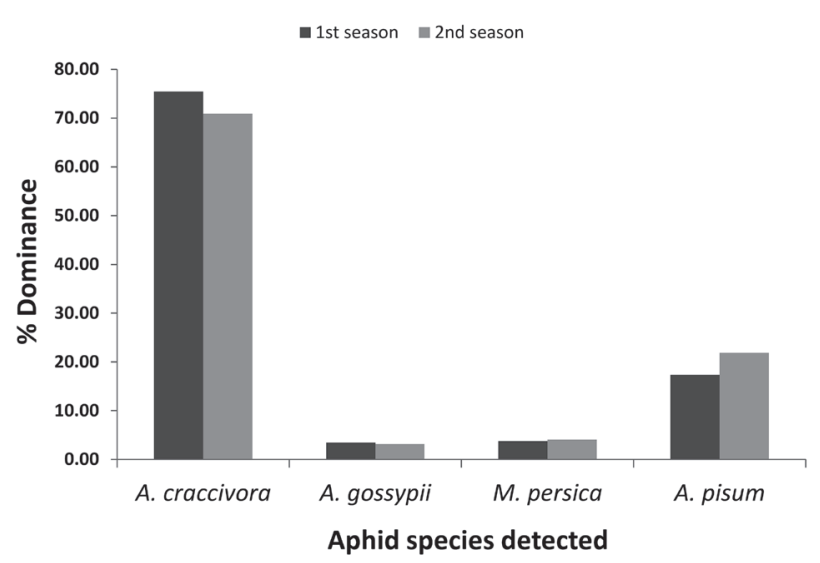

Fig. 2. Dominance percentages of the four aphid species detected in faba bean fields.

the end of the 2016/2017 season, and a density peak appeared on Mar. $28^{\text {th }}$ when the mean density was 55.00 \pm 15.13 individuals, but in the $2017 / 2018$ season, $A$. pisum appeared much earlier, and the peak was found on Jan. $6^{\text {th }}$ with the mean density of $35.8 \pm 26.6$, then it disappeared again till the harvest time (Fig. 1).

The dominance percentage showed that cowpea aphid was the major pest aphid in our region; it achieved $75.42 \%$ and $70.91 \%$ in the $2016 / 2017$ and $2017 / 2018$ surveys, respectively, and the dominance percentages were followed by A. pisum and M. persicae, and A. gossypii (Fig. 2). It was therefore noticed that $A$. craccivora was the most dominant species, which could increase rapidly in the early stage of faba bean and one distinct population peak appeared in late December or early January (Fig. 1). Care should thus be taken to monitor this pest aphid, in particular, in the early planting season.

Awadalla et al. (2016) recorded two peaks for $A$. craccivora, $M$. persicae and $A$. pisum on broad bean, and the first and second peaks were at the fourth week of January and second week of March, respectively. Also, Awadalla et al. $(2013,2014)$ mentioned that A. craccivora and $M$. persicae had two peaks on faba bean. The difference between our study and Awadalla et al. may arise because of the difference in climate conditions between the study localities. In previous studies in Egypt, some authors suggest an influence of relative humidity or other climate conditions on aphid populations in bean fields (e.g., Khalafalla and El-Galaly, 1998; Salman and Mohamed, 2000). However, it is unclear how abiotic factors including climate conditions could affect pest aphids like $A$. craccivora in faba bean fields. The importance of abiotic factors determining pest aphid population dynamics will thus be one of the main subjects in future studies.

\section{Aphid predators}

In our study field, a variety of arthropod predators associated with aphids were detected on faba bean plants (Fig. 3). The main predators detected were common green lacewing Chrysoperla carnea (Steph.) (both larval and adult stages), eleven-spot ladybird Coccinella undecimpunctata L. (both larval and adult stages), minute pirate bug Orius sp. (both nymphal and adult stages), rove beetle Paederus alfierii Koch (adult stage only), lady beetle Scymnus spp. (both larval and adult stages) and two species of true spiders, Singa sp. and Dictyna sp. The two true spider species are combined and reported in Fig. 3 as "true spiders" because of their low numbers.

In the 2016/2017, predators began to appear from the earliest growth stage of faba bean (Fig. 3A). Ch. carnea was the most dominant predator with the mean dominance percentage of $28.05 \%$, followed by true spiders with $23.76 \%$, while Orius sp. was the least abundant predator (Fig. 4). Fewer numbers of predators were occurred in 2017/2018 (Fig. 3B). However, Ch. carnea again was the most abundant species (25.09\%) while $P$. alfierii was the least one (Fig. 4). It was noticeable that, in 2017/2018, predator densities increased in the last week of the field study period, and that population dynamics differed markedly between the two study seasons.

El-Sarand (2013) found four common insect predators associated with aphids in Kafr El-Sheikh; Ch. Carnea, P. alfierii, C. undecimpuntata and Scymnus spp., and also found the green lacewing was the most abundant while Scymnus was the least. Our present study therefore agrees with El-Sarand (2013) study. In other Egyptian geographical region, e.g., El-Khrga Oasis at western Egypt, Abdel Khlek et al. (2018) showed that C. undecimpunctata was the most dominant predator in faba bean fields. This may be due to the geographic and environmental differences; while our studied field located in the delta of Egypt, El-Khrga Oasis was at a dry area in the middle of the western desert. Thus, composition and abundance of aphid predators can differ depending on the year and locality, presumably reflecting their biotic and abiotic preferences.

\section{Aphid parasitoids}

The present surveys on aphid parasitism revealed that the aphid $A$. craccivora suffered from high levels of parasitism by parasitoid wasps (Fig. 5). The major genus of the parasitoids was identified as Aphidius (Hymenoptera: Aphidiidae). No statistical difference was detected in mean parasitism rates between the two study seasons $(\mathrm{F}=1.199, P<0.28)$. The mean parasitism rates started from high values, i.e., $50 \%$ and $56 \%$ for first and second seasons, respectively, and, then, reached 100\% parasitism (Fig. 5). However in the 2016/2017 season, the parasitism rate became $0 \%$ in the fifth sampling date, and no parasitism was detected till the end of the season; in 2017/2018, the parasitism rates remained high until the $8^{\text {th }}$ week, and became $0 \%$ thereafter (Fig. 5).

Thus, the present study has shown that aphid parasitoids can play an important role in suppressing $A$. craccivora populations; the activity of the parasitoid Aphidius spp. is very high during the early to middle stages of faba bean when the host aphid A. craccivora is abundant, and the percentages of parasitism overall are fairly high during the period. The conservation of such 

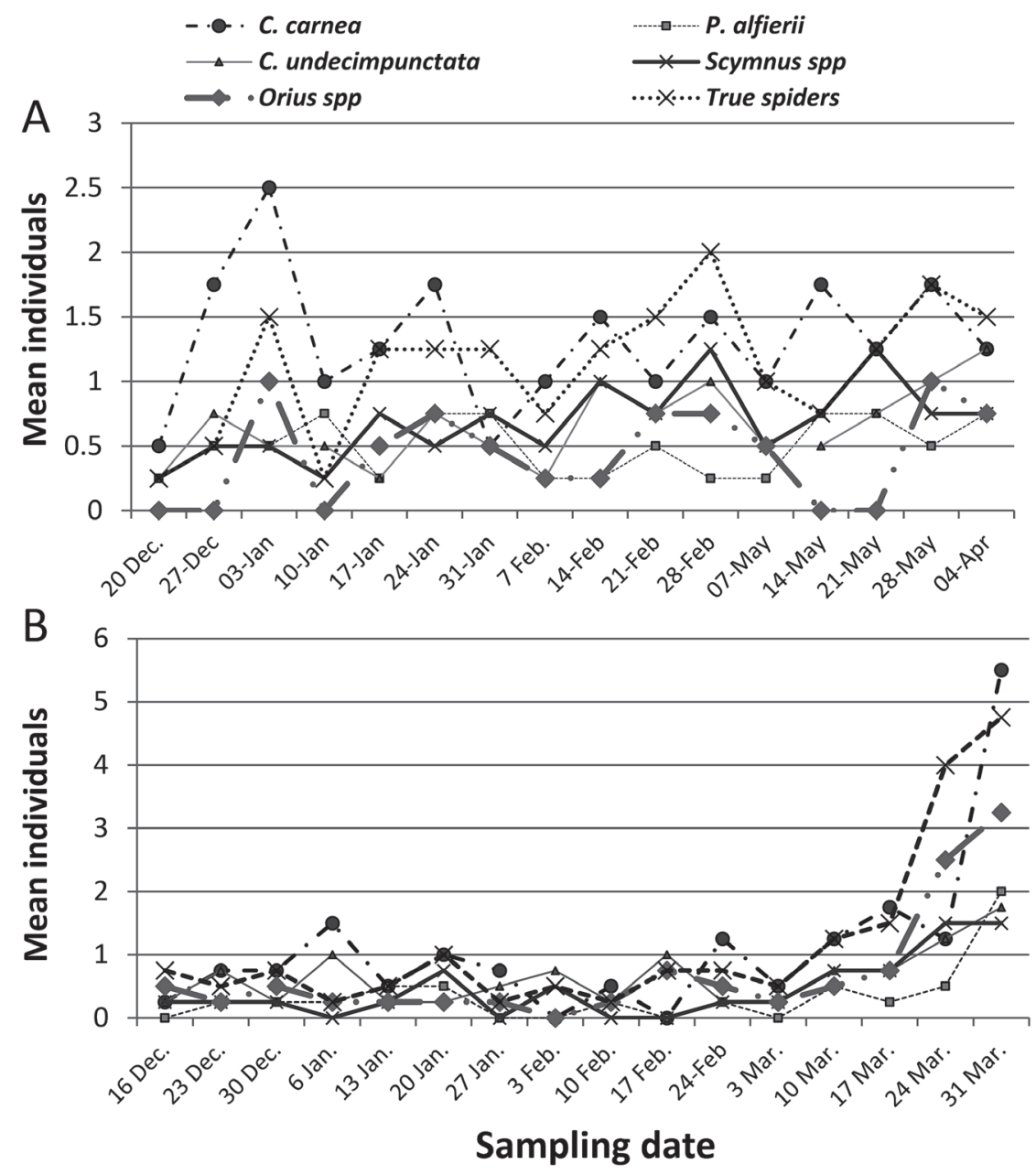

Fig. 3. Mean weekly abundance of aphid-associated predators in faba bean fields during 2016/2017 (A) and 2017/2018 (B) seasons.

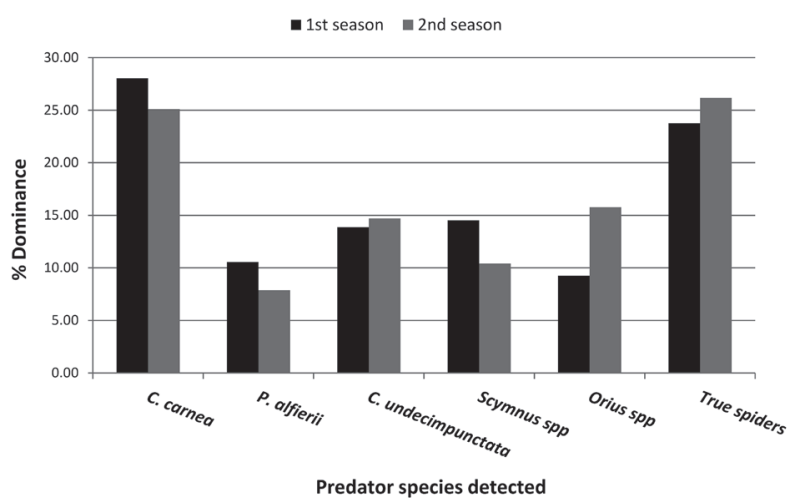

Fig. 4. Dominance percentages of the predatory species associated with aphids in faba bean fields.

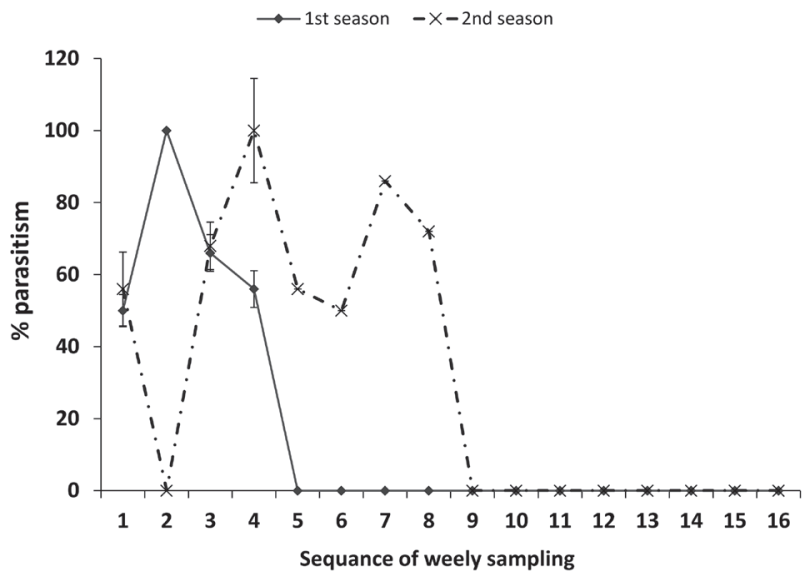

Fig. 5. The relationships between the sampling dates (from December $20^{\text {th }} 2016$ to Apr. $4^{\text {th }} 2017$ in 2016/2017 season and from Dec. $16^{\text {th }} 2017$ to Mar. $31^{\text {st }} 2018$ in 2017/2018 season) and the parasitism percentages of the aphid parasitoid Aphidius spp. in faba bean fields. Vertical lines indicate standard errors. 
aphid parasitoids should be important in IPM of faba bean production. Also, the exact identification of the Aphidius species will be done and the species composition should be revealed in future.

The levels of parasitoid activity appear to differ between the 2016/2017 and 2017/2018 seasons. In the latter season, parasitism rate remained high until the middle of growing season. It is unknown what factors are involved in such a difference. It is well known that humidity and temperature considerably affect life expectancy and reproduction of small insects, including aphid parasitoids (Stary, 1970; Giga and Smith, 1983; Fink and Völkl, 1995; Aung et al., 2011; Tran et al., 2012). The natural enemies and climatic conditions are of the most important factors affecting the population dynamics of insect pests (Bylund, 1999; Alalouni et al., 2013; Bassiony et al., 2017). We suspect the difference in weather or climate conditions could be associated with it but further field surveys are required to examine how such abiotic conditions affect the activity of parasitoids and predators.

\section{AUTHORS' CONTRIBUTIONS}

In the present study, I. A. Khodeir and M. A. Khattab designed the study and prepared the first draft of the manuscript. K. M. Mousa analyzed the data, wrote the manuscript and discussed the results. A. S. Sharabash conducted the field experiments, and O. M. Rakha helped during the experiment. T. Ueno discussed the results, polished up the research concept and the manuscript.

\section{CONFLICT OF INTEREST}

The authors declare no conflicts of interest.

\section{REFERENCES}

Abdel Khalek, S. T., Z. K. Mostafa, H. A. Hassan, M. M. Abd El-Bar and G. M. M. Abu El-Hassan 2018 A new list to the entomofauna associated with faba bean, Vicia faba L. (Fabales: Fabaceae) grown in El-Kharga Oasis, New Valley Governorate, Egypt. Egypt. Acad. J. Biol. Sci., 11: 95-100

Alalouni U., M. Schädler and R. Brandl 2013 Natural enemies and environmental factors affecting the population dynamics of the gypsy moth. J. Appl. Entomol., 137: 721-738

Aung, K.S.D., T. Ueno and M. Takagi 2011 Effect of temperature on lifetime reproduction of the egg parasitoid Ooencyrtus nezarae (Ishii) (Hymenoptera: Encyrtidae). J. Fac. Agric., Kyushu Univ., 56: 67-70

Awadalla, H. S. S., H. A. EL-Kady, E. F. EL- Khyatt and M. A. M. Hegab 2016 Ecological studies on aphid species infesting different leguminous vegetable plant varieties with regard to their seasonal abundance. J. Plant Prot. Pathol., Mansoura Univ., 7: 733-740

Awadalla, S. S., F. E. Abdallah and N. R. EL-Mashaly 2013 Influence of some varieties on the main insect pests attacking faba bean plants. J. Plant Prot. Pathol., Mansoura Univ., 4: $581-589$

Awadalla, S. S., F. E. Abdallah and N. R. EL-Mashaly 2014 Population density of main insect pests attacking faba bean plants as influenced by sowing dates. Glob. J. Agric. Food Safety Sci., 1: 169-177
Bassiony, R. A., F. A. Abou-attia, M. A. Samy, A. E. Youssef and T. Ueno 2017 Infestation caused by the agromyzid leafminer Liriomyza trifolii of bean crops in Kafr EL-Shiekh, Egypt. J. Fac. Agr., Kyushu Univ., 62: 435-438

Bylund, H. 1999 Climate and the population dynamics of two insect outbreak species in the North. Ecol. Bull., 47: 54-62

Denholm, I. and M. W. Rowland 1992 Tactics for managing pesticide resistance in arthropods: theory and practice. Annu. Rev. Entomol., 37: 91-112

Dent, D. 2000 Insect Pest Management, CABI Publishing, London, UK, 2nd edition

El-Dfrawi, G. M. and S. A. Mokhtar 2007 Evaluation of some faba bean (Vicia faba L.) genotypes for resistance to cowpea aphid, Aphis craccivora Koch. Egypt. J. Appl. Sci., 22(6A): 294-309

El-Sarand, E. A. 2013 Integrated management of certain piercing-sucking insects on soy bean and faba bean plants at Kafr ElShiekh Governorate. Ph.D.Thesis, Fac. of Agric. Tanta Univ., pp 224

Elsharkawy, M. M. and K. M. Mousa 2015 Induction of systemic resistance against papaya ring spot virus (PRSV) and its vector Myzus persicae by Penicillium simplicissimum GP17-2 and silica (Sio2) nanopowder. Inter. J. Pest Manage., 61: 353-358

Fasulati, K. K. 1971 Field Studies of Terrestrial Invertebrates. $2^{\text {nd }}$ ed. Vysshaya Shkola Press, Moscow, USSR. 424 pp

Farrell, J. A. and M. W. Stufkens 1990 The impact of Aphidius rhopalosiphi (Hymenoptera: Aphidiidae) on populations of the rose grain aphid (Metopolophium dirhodum) (Homoptera: Aphididae) on cereals in Canterbury, New Zeland. Bull. Ent. Res., 80: 377-383

Fink, U. and W. Völkl 1995 The effect of abiotic factors on foraging and oviposition success of the aphid parasitoid, Aphidius rosae. Oecologia, 103: 371-378

Giga, D. R. and R. H. Smith 1983 Comparative life-history studies of four Callosobruchus species infesting cowpeas with special reference to Callosobruchus rhodesianus (Pic) (Coleoptera: Bruchidae). J. Stored Prod. Res. 19: 189-198

Gupta, Y. P. 1982 Nutritive value of food legumes. In "Chemistry and Biochemistry of Legumes". ed by S. K. Arora, Oxford and IBH Puplishing Co., New Delhi, pp. 287-327

Hannou, M. A. 1995 Insects, snails, diseases and weeds associated with broad bean fields in Alexandria. Egypt. J. Appl. Sci., 10: $351-358$

Hossni, S. A. 2004 Ecological and biological studies on different aphid species infesting some legume plants in Egypt. MSc thesis, Benha University

Hull, R. 1964 Spread of groundnut rosette virus by Aphis craccivora (Koch). Nature, 202: 213-214

Khalafalla, E. M. E. and O. A. M. El- Galaly 1998 Main insects of faba bean and yield in relation to sowing dates at Kafr El-Sheikh region. J. Agric. Res. Tanta Univ., 24: 282-291

Khattab, M. A., E. M. E. Khalafalla and R. A. I. Abou Mostafa 2014 Field evaluation of certain faba bean genotypes to Aphis craccivora Koch infestation with special reference to yield. Egypt. J. Plant Prot. Res., 2: 36-47

Mousa, K. M. and T. Ueno 2019 Intercropping potato with citrus trees as ecologically-based insect pest management. J. Fac. Agr., Kyushu Univ., 64: 71-78

Mousa, K. M., I. A. Khodeir, T. N. El-Dakhakhni and A. E. Youssef 2013 Effect of garlic and eucalyptus oils in comparison to organophosphate insecticides against some piercing-sucking faba bean insect pests and natural enemies populations. Egypt. Acad. J. Biolog. Sci., 5: 21-27

Mousa, K. M., O. M. Rakha and T. Ueno 2019 Relationships between development time, reproductive period, fecundity and longevity at the within-individual level in the cowpea aphid Aphis craccivora Koch (Homoptera: Aphididae). J. Fac. Agr., Kyushu Univ., 64: 101-106

Radcliffe, E. B., K. L. Flanders and D. W. Ragsdale 1993 Management of aphids and leafhoppers. In "Potato Health Management", ed by R. C. Rowe, APS Press, St. Paul, Minnesota, pp. $103-115$

Salman F. A. A. and A. M. Mohamed 2000 Occurrence and abun- 
dance of cowpea, Aphis craccivora (Koch.) infesting faba bean plants at different sites of the fields in Upper Egypt. Assuit $J$. Agric. Sci., 31: 299-310

Stary, P. 1970 Biology of Aphid Parasites, with Respect to Integrated Control. Series Entomology 6, Junk, Den Haag

Sun, M., R. E. Voorrips, G. Steenhuis-Broers, W. V. Westende and B. Vosman 2018 Reduced phloem uptake of Myzus persicae on an aphid resistant pepper accession. BMC Plant Biol., 18: 138

Tran, D. H., K. P. Le, T. Ueno and M. Takagi 2012 Effect of temperature and host on the immature development of the parasitoid Neochrysocharis okazakii (Hymenoptera: Eulophidae). J. Fac. Agric., Kyushu Univ., 57: 133-137
Tran, D. H., K. P. Le, H. D. T. Tran and T. Ueno 2016 Control efficacy of pongam (Pongamia pinnata L.) leaf extract against the turnip aphid Lipaphis pseudobrassicae (Davis) (Hemiptera: Aphididae). J. Fac. Agric., Kyushu Univ., 61: 141-145

Tran, D. H., M. Takagi and T. Ueno 2017 Efficacy of the extract from pongam leaves (Pongamia pinnata L.) against Spodoptera exigua (Hübner) and Spodoptera litura Fabricius (Lepidoptera: Noctuidae). J. Fac. Agric., Kyushu Univ., 62: 439-443

Ueno, T. 2006 Current status of insect pests attacking green bunching onionin Central and Southern Vietnam. J. Fac. Agric., Kyushu Univ., 51: 275-283 